Goldschmidt 2021 Abstract

https://doi.org/10.7185/gold2021.3818

\section{Diagenetic origin of Ca-dominated brine in the Athabasca Basin - a geochemical path modeling}

\section{YUMENG WANG AND GUOXIANG CHI}

University of Regina

Presenting Author: geomeng@foxmail.com

The formation of world-class unconformity-related $U$ deposits in the Athabasca Basin (Canada) is related to basinal brines intially derived from evaporated seawater. Previous fluid inclusion studies show that the ore fluids range from $\mathrm{Na}$ dominated to $\mathrm{Ca}$-dominated brines. The latter was considered to have evolved from the former as a result of basinal brines reacting with Ca-rich minerals in the basin or basement. However, due to the scarcity $(<5$ vol.\%) of Ca-rich minerals in the currently preserved sedimentary rocks in the basin, it has been questioned whether $\mathrm{Ca}$-dominated brines could be produced within the basin during diagenesis. In this study, we examine this problem through geochemical path modeling using Geochemist's Workbench (GWB).

Two scenarios of titration path modeling were conducted at $100{ }^{\circ} \mathrm{C}$ : 1) a Na-dominated brine reacts with a sandstone composed of 5 vol $\%$ Ca-plagioclase, 5 vol $\% \mathrm{~K}$-feldspar and 90 vol\% quartz; 2) a Mg-dominated brine reacts with a pure limestone composed of $100 \mathrm{vol} \%$ calcite. The results of scenario 1 show that at high fluid/rock mass ratios $(\mathrm{F} / \mathrm{R}>1)$, the brine is Na-dominated and is in equilibrium with quartz + muscovite + clinochlorite + anhydrite. In contrast, at low F/R $(<0.25)$, the brine becomes Ca-dominated and the equilibrium mineral assemblage is quartz + muscovite + clinochlore + albite + anhydrite + K-feldspar (Fig. 1a, b). The results of scenario 2 show that the Mg-dominated brine becomes Ca-dominated at F/R ratio as high as 7 , and becomes $\mathrm{Mg}$-depleted at $\mathrm{F} / \mathrm{R}<3$, in equilibrium with dolomite + caclite + anhydrite (Fig. 1c, d). Based on the record of dolomite in the upper part of the Athabasca Basin and scarcity of albite, and the limition of scenario 1 imposed by very low $\mathrm{F} / \mathrm{R}$ ratios, dolomitization (scenario two) is considered as the likely mechanism for forming Ca-dominated brine in the Athabasca Basin.

Fig. 1 Calculated mass of minerals $(a, c)$ and concentration of major fluid components (b, d) at $100^{\circ} \mathrm{C}$ as a function of sandstone mass titrated into $1 \mathrm{~kg} \mathrm{Na}$-dominated brine $(\mathrm{a}, \mathrm{b})$ or as a function of limestone mass titrated in $1 \mathrm{~kg} \mathrm{Mg}$-dominated brine (c, d).
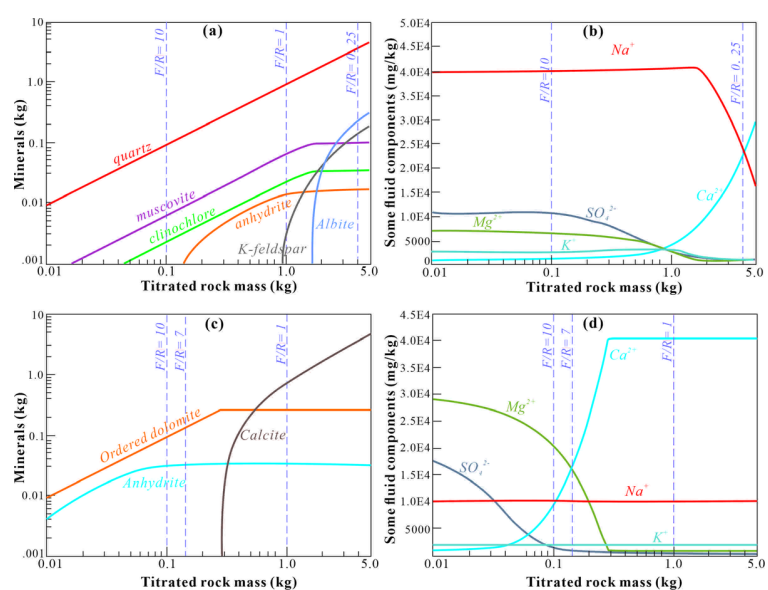